PENELITIAN

\title{
PENGARUH PEMBERIAN AROMATERAPI PEPPERMINT INHALASI TERHADAP MUAL MUNTAH PADA PASIEN POST OPERASI DENGAN ANESTESI UMUM
}

\author{
Tori Rihiantoro*, Candra Oktavia*, Giri Udani* \\ *Jurusan Keperawatan Poltekkes Tanjungkarang \\ E-mail: toririhiantoro@gmail.com
}

\begin{abstract}
Penggunaan anestesi umum dapat menyebabkan pasien mengalami mual, muntah (sering dikenal dengan istilah $P O N V$ ). Insidensi $P O N V$ mencapai $30 \%$ dari 100 juta lebih pasien bedah di seluruh dunia. Di Indonesia insiden terjadinya $P O N V$ belum tercatat jelas. Penanganan $P O N V$ dapat menggunakan terapi farmakologi dan nonfarmakologi. Salah satu terapi non farmalkologi yaitu pemberian aromaterapi peppermint secara inhalasi. Tujuan penelitian ini adalah untuk mengetahui pengaruh pemberian aromaterapi peppermint inhalasi terhadap mual muntah pada pasien post operasi dengan anestesi umum. Desain penelitian yang digunakan adalah Quasi Eksperimen dengan rancangan Non Equivalent Control Group. Populasi pada penelitian ini adalah pasien post operasi dengan anestesi umum dengan jumlah sampel 20 orang. Hasil penelitian menyimpulkan ada perbedaan skor rata-rata PONV sebelum dan sesudah diberikan aromaterapi peppermint inhalasi pada kelompok eksperimen yaitu 11.10 ( $p$ value $=0.005)$, ada perbedaan skor rata-rata $P O N V$ pada pengukuran pertama dan pengukuran kedua pada kelompok control yaitu 2.20 ( $p$ value $=0.006$ ), selanjutnya juga ada perbedaan selisih skor rata-rata $P O N V$ pada kelompok eksperimen dengan kelompok kontrol yaitu 10.00 ( $p$ value+0.000). Hasil ini menunjukkan bahwa aromaterapi peppermint memberikan pengaruh dalam menurunkan skor rata-rata $P O N V$ pada pasien post operasi dengan anastesi umum. Oleh karena itu, peneliti merekomendasikan untuk penerapan terapi aromatik peppermint pada pasien post operasi yang mengalami keluhan mual muntah.
\end{abstract}

\section{Kata kunci: Anestesi Umum, PONV (Mual Muntah Post Operasi), Aromaterapi Peppermint}

\section{LATAR BELAKANG}

Tindakan pembedahan sebagai salah salah satu alternatif terapi pada pasien yang mengalami gangguan kesehatan terus meningkat insidensinya dari tahun ketahun. World Health organization (WHO) dalam penelitian Hartoyo (2015) menyatakan bahwa jumlah pasien yang dilakukan pembedahan tiap tahun mengalami peningkatan. Jumlah pasien dengan tindakan pembedahan mencapai 140 juta jiwa di seluruh rumah sakit dunia pada tahun 2011 dan meningkat menjadi 148 juta jiwa pada tahun 2012. Sementara di Indonesia, jumlah pasien yang dilakukan pembedahan mencapai 1,2 juta jiwa pada tahun 2012.

Sebagian besar tindakan pembedahan yang dilakukan pada pasien menggunakan anastesi umum. Anestesi umum pada pembedahan dapat menyebabkan permasalahan antara lain mual, muntah, batuk kering, nyeri tenggorokan, pusing, nyeri kepala, nyeri punggung, gatal-gatal, lebam di area injeksi serta hilang ingatan sementara (Allen, 2004; Conway, 2009; Hewitt \& Watts, 2009 dalam Supatmi \& Agustiningsih, 2015). Pasien-pasien dianestesi umum mempunyai resiko yang lebih tinggi untuk mengalami mual dan muntah dibandingkan dengan pasien yang menggunakan jenis anestesi lain (Islam \& Jain, 2004 dalam Indrawati, 2010).

Mual muntah post operasi dikenal dengan istilah Post Operative Nausea And Vomiting (PONV). Menurut GAN, T.J (2006) dalam Silaban (2015) PONV adalah komplikasi yang sering terjadi pada anestesi umum dalam 24 jam pertama setelah operasi.

Insidensi PONV mencapai $30 \%$ dari 100 juta lebih pasien bedah di seluruh dunia (Sholihah, Marwan \& Husairi, 2015). Setiap tahun sebanyak 71 juta pasien bedah umum di Amerika Serikat mengalami insiden $P O N V$ sebanyak 20 $30 \%$ dan sekitar $70-80 \%$ pada kelompok 
dengan resiko tinggi (Wijaya, Fithrah, Marsaban \& Hidayat, 2014). Jenis pembedahan yang beresiko tinggi terjadi $P O N V$ antara lain bedah plastic $45 \%$, bedah abdominal $29 \%$ dan bedah orthopedi 22\% (Juliana, Irawan \& Hamidy, 2013).

Di Indonesia insiden terjadinya $P O N V$ belum tercatat jelas. Berdasrkan penelitian Wijaya, Fithrah, Marsaban \& Hidayat (2014) kejadian PONV pada pembedahan laparatomi dan ginekologi sebesar $31,25 \%$ dan pembedahan mastektomi sebesar 31,4\%. Hasil penelitian Sholihah, Sikumbang \& Husairi (2015) juga melaporkan dari 96 pasien, 26 pasien (27.08\%) mengalami PONV. Hasil penelitian sejenis oleh Saeeda Islam et al. dalam Sholihah, Sikumbang \& Husairi (2015) melaporkan insiden PONV pada pasien pembedahan berkisar antara 20$30 \%$. Penelitian lainnya oleh Duck Hwan Choi et al. terdapat $39 \%$ pasien mengalami satu atau lebih kejadian PONV dan pada penelitian Sadqa Aftab et al. sebanyak 30\% mengalami PONV (Sholihah, Sikumbang \& Husairi. 2015). Sedangkan insidensi mual pada 2 jam pertama post operasi di PACU (Post Anesthesia Care Unit) mencapai $20 \%$ dan muntah $5 \%$. Sedangkan pada 2 jam berikutnya sampai 24 jam insidensi mencapai $50 \%$ dan muntah 25\% (Kovac, 2003 dalam Silaban, 2015).

Terjadinya PONV bila tidak
ditangani dengan segera dapat
menyebebkan timbulnya masalah baru.
$P O N V$ dapat menyebabkan dehidrasi, ketidakseimbangan elektrolit, hipertensi vena, perdarahan, ruptur esofageal, dan dalam keadaan lanjut dapat membuat pasien mengalami dehidrahi berat (Conway, 2009 dalam Supatmi \& Agustiningsih, 2015). Selain itu, PONV juga dapat menyebabkan stress post operasi dan kecenderungan malas latihan gerak atau ambulasi dini pada pasien (Allen, 2004 dalam Supatmi \& Agustiningsih, 2015). Dampak lebih lanjut dari $P O N V$ apabila tidak ditangani maka dapat memperpanjang waktu perawatan, meningkatkan biaya perawatan dan dapat menyebabkan peningkatan stressor
(Buckle, 2007 dalam Supatmi \& Agustiningsih, 2015). Oleh karena itu perawat harus memahami dengan benar kondisi mual dan muntah yang dialami pasien dan bagaimana penangananya untuk mencegah dampak lebih lanjut dari $P O N V$.

Penanganan $P O N V$ dapat dilakukan secara farmakologi dengan obat antiemetik dan non farmakologi (Utomo, Sudirman \& Syafi'i, 2009). Obat antiemetik kelas baru untuk pencegahan dan penanganan mual muntah post operasi adalah antagonis reseptor serotonin (5-HT), diantaranya ondansetron. Penggunaan antagonis reseptor serotonin masih menimbulkan efek samping berupa konstipasi, sakit kepala, mengantuk, gangguan saluran cerna, nyeri dada, dan susah bernafas (Sulistia, 2007; Farid \& Ramli, 2005 dalam Indrawati, 2010). Selain itu, menurut Utomo, Sudirman \& Syafi'i (2009) belum ditemukan obat antiemetik yang efektif yang dapat mencegah mual dan muntah secara total dan tanpa adanya efek samping.

Alternatif lain yang dapat dilakukan untuk mengatasi PONV adalah dengan terapi non farmakologi. Penanganan menggunakan terapi non farmakologi atau komplementer pada berbagai masalah kesehatan semakin meningkat, karena dalam pelaksanaannya relatif mudah dan juga tidak menimbulkan efek samping.

Pada beberapa kasus penyakit terapi farmakologi lebih efektif dampaknya jika diberikan bersamaan dengan pemberian terapi komplementer pada pasien (Solehati \& Kosasih, 2015). Sedangkan menurut Hewitt \& Watts (2009) dalam Supatmi \& Agustiningsih (2015) penggunaan terapi komplementer relatif mudah, relatif murah, efektif mengurangi mual dan muntah, menarik dan dapat diterima pasien.

Terapi komplementer yang dapat digunakan untuk mencegah dan mengurangi mual muntah post operasi salah satunya yaitu menggunakan aromaterapi. Salah satu sumber minyak harum yang digunakan sebagai aromaterapi antara lain berasal dari peppermint, bunga lavender, bunga mawar, jahe dan lemon (Allen, 2004; Buckle, 
2007; Kim, et all, 2007 dalam Supatmi \& Agustiningsih, 2015).

Aromaterapi peppermint adalah salah satu aromaterapi yang dapat digunakan untuk melemaskan otot-otot yang kram, memperbaiki gangguan ingestion, digestion, menurunkan terjadinya mual dan muntah serta mengatasi ketidakmampun flatus. (Snyder \& Lindquist, 2010 dalam Supatmi \& Agustiningsih, 2015). Penelitian terkait yang dilakukan oleh Supatmi \& Agustiningsih (2015) menyimpulkan bahwa secara umum aromaterapi jenis pepermint yang diberikan secara inhalasi, efektif menurunkan mual dan muntah. Hasil penelitian oleh Susanti (2016) juga menunjukan pengaruh yang terhadap penurunan skala mual antara sebelum dan setelah pemberian aromaterapi peppermint pada pasien kemoterapi. Hasil penelitian lain oleh Santi (2013) juga menunjukan pengaruh aromaterapi blended peppermint dan ginger oil terhadap rasa mual pada ibu hamil trimester.

\section{METODE}

Desain penelitian yang digunakan dalam penelitian ini adalah quasi eksperiment design dengan rancangan penelitian non-equivalent control group. Rancangan ini disebut juga non randomized control grup pretest postests design. Responden dibagi ke dalam kelompok eksperimen dan kelompok kontrol.

Pada kelompok eksperimen: tahap pretest dilakukan pengukuran PONV pada pasien dengan anestesi umum, pada perlakuan dilakukan pemberian aromaterapi peppermint inhalasi dan pada tahap posttest dilakukan pengukuran PONV kembali pada pasien dengan anestesi umum yang yang telah diberikan aromaterapi peppermint inhalasi.

Sedangkan pada kelompok kontrol: tahap pretest dilakukan pengukuran PONV, tahap perlakuan tidak dilakukan pemberian aromaterapi peppermint inhalasi, namun diganti dengan pemberian plasebo (air hangat) inhalasi dan pada tahap posttest dilakukan pengukuran PONV kembali setelah diberikan pemberian plasebo (air hangat) inhalasi.

Populasi dalam penelitian ini adalah pasien post operasi dengan anastesi umum yang berjumlah 75 pasien. Berdasarkan perhitungan rumus sampel $\mathrm{n}=\left[\frac{(Z \alpha+Z \beta) \mathrm{S}}{X 1-X 2}\right]^{2}, \quad$ maka jumlah sampel 10 orang untuk masing-masing kelompok, dengan kriteria pasien: mengalami mual/muntah, diberikan premedikasi obat antiemetic, 6-24 jam post operasi, sadar penuh, indra penciuman baik, tidak mengalami kanker, tidak mengalami gangguan sirkulasi, tidak memiliki gangguan jantung, tidak menderita migran, tidak hamil pada trimester pertama dan tidak mempunyai asma parah atau riwayat beberapa alergi.

Data PONV pasien dikumpulkan dengan menggunakan lembar kuesioner Rhodes Index of Nausea, Vomiting, and Retching (RINVR) dan lembar observasi. Menurut Kim, Choi, Chin, Lee, Kim and Noh (2007) dalam Supatmi \& Agustiningsih (2015), RINVR merupakan instrumen untuk menilai mual dan muntah yang terdiri dari delapan pernyataan dengan lima pilihan jawaban yang mengkaji secara subyektif dan obyektif. Instrumen ini memiliki tingkat validitas dan reliabilitas yang tinggi, dimana nilai Cronbach's alpha 0.912-0,968, Spearman's coeficient: 0,9621,000, P < 0,0001 . Instrumen ini digunakan pada 6 jam setelah operasi. Skor minimal instrumen RINVR adalah 0 dan skor tertinggi 32.

Pengumpulan data pada penelitian ini dilakukan di kelas II maupun kelas III yang terbagi atas beberapa ruangan. Dalam penetapan responden, peneliti tidak melakukan penelitian dalam 1 ruangan antara kelompok eksperimen dan kelompok kontrol, namun dengan ruangan berbeda dan waktu pengumpulan data juga berbeda.

Data penelitian selanjutnya dianalisis secara univariat dan bivariat. Sebelum dilakukan anailisis ststistik secara bivariat, data terlebih dahulu dilakukan uji 
normalitas data dan diperoleh hasil distribusi data tidak normal, sehingga uji statistik pada penelitian ini menggunakan uji non parametris: uji Wilcoxon dan uji Man- Whitney. Pada uji Wilcoxon dan uji Man-Whitney, jika $p$ value $<0.05$, maka H0 ditolak.

\section{HASIL}

\section{Karakteristik Responden}

Responden pada penelitian ini memiliki karekteristik jenis kelamin perempuan (100\%), sebagian besar berusia $>45$ tahun pada kelompok eksperimen $(80 \%)$ dan pada kelompok kontrol $(50 \%)$, jenis operasi terbanyak pada kelompok eksperimen adalah mastektomi (30\%), sedangkan pada kelompok kontrol adalah tiroidektomi (30\%). Namun jika dilihat jenis operasi terbanyak pada kedua kelompok yang terbanyak adalah tiroidektomi (50\%).

\section{Analisis Univariat}

Tabel 1: Distribusi Skor PONV pada Kelompok Eksperimen

\begin{tabular}{ccccccc}
\hline $\begin{array}{c}\text { Skor } \\
\text { PONV }\end{array}$ & $\mathrm{n}$ & Mean & Med & \multicolumn{2}{c}{ SD } & \multicolumn{2}{c}{ Min Maks } \\
\hline Sebelum & 10 & 14.40 & 14.50 & 4.90 & 8 & 22 \\
\hline Setelah & 10 & 3.30 & 3.00 & 2.21 & 0 & 7 \\
\hline
\end{tabular}

Berdasarkan tabel di atas dapat diketahui bahwa skor rata-rata $P O N V$ sebelum diberikan aromaterapi peppermint inhalasi adalah 14.40 dengan standar deviasi 4.90, skor $P O N V$ terendah adalah 8 dan skor $P O N V$ tertinggi adalah 22. Sedangkan, skor rata-rata $P O N V$ setelah diberikan aromaterapi peppermint inhalasi adalah 3.30 dengan standar deviasi 2.21, skor $P O N V$ terendah adalah 0 dan skor $P O N V$ tertinggi adalah 7.

Tabel 2: Distribusi Skor PONV pada Kelompok Kontrol
Skor
PONV n Mean Med SD Min Maks

\begin{tabular}{llllll} 
Sebelum 10 & 9.70 & 9.50 & 2.31 & 6 & 12 \\
\hline
\end{tabular}

\begin{tabular}{lllllll}
\hline Setelah & 10 & 7.50 & 8.00 & 2.12 & 4 & 10
\end{tabular}

Berdasarkan tabel di atas dapat diketahui bahwa skor rata-rata $P O N V$ pada pengukuran pertama adalah 9.70 dengan standar deviasi 2.31, skor PONV terendah adalah 6 dan skor $P O N V$ tertinggi adalah 12. Sedangkan, skor rata-rata $P O N V$ pada pengukuran kedua adalah 7.50 dengan standar deviasi 2.12, skor PONV terendah adalah 4 dan skor $P O N V$ tertinggi adalah 10 .

\section{Analisis Bivariat}

Tabel 3: Distribusi Perbedaan Skor PONV Sebelum dan Setelah diberikan Aromaterapi Peppermint Inhalasi pada Kelompok Ekperimen.

\begin{tabular}{lcccc}
\hline Skor PONV & Mean & SD & p value & $\mathrm{n}$ \\
\cline { 1 - 3 } Sebelum & 14.40 & 4.90 & \multirow{2}{*}{0.005} & \multirow{2}{*}{10} \\
\cline { 1 - 4 } Setelah & 3.30 & 2.21 & & \\
\hline
\end{tabular}

Berdasarkan tabel di atas dapat diketahui bahwa perbedaan skor rata-rata $P O N V$ sebelum dan setelah diberikan aromaterapi peppermint inhalasi adalah 11.10. Hasil analisis uji Wilcoxon didapatkan $p$ value $0.005<\alpha(0.05)$, maka dapat disimpulkan bahwa terdapat perbedaan skor rata-rata $P O N V$ sebelum dan setelah diberikan aromaterapi peppermint inhalasi pada kelompok ekperimen.

Tabel 4: Distribusi Perbedaan Skor PONV Sebelum dan Setelah diberikan Plasebo pada pada Kelompok Kontrol.

\begin{tabular}{lcccc}
\hline Skor PONV & Mean & SD & p value & $\mathrm{n}$ \\
\cline { 1 - 3 } Sebelum & 9.70 & 2.31 & \multirow{2}{*}{0.006} & \multirow{2}{*}{10} \\
\cline { 1 - 3 } Setelah & 7.50 & 2.12 & & \\
\hline
\end{tabular}

Berdasarkan tabel di atas dapat diketahui bahwa perbedaan skor rata-rata $P O N V$ pada pengukuran pertama dan pengukuran kedua pada kelompok kontrol adalah 2.20. Hasil analisis uji Wilcoxon 
didapatkan $p$ value $0.006<\alpha(0.05)$, maka dapat disimpulkan bahwa terdapat perbedaan skor rata-rata $P O N V$ pada pengukuran pertama dan pengukuran kedua pada kelompok kontrol.

Tabel 5: Distribusi Perbedaan Selisih Skor PONV pada Kelompok Ekperimen dan Kelompok Kontrol.

\begin{tabular}{lllll}
\hline $\begin{array}{l}\text { Selisih Skor } \\
\text { PONV }\end{array}$ & $\begin{array}{c}\text { Mean } \\
\text { Rank }\end{array}$ & $\begin{array}{c}\text { Sum of } \\
\text { Rank }\end{array}$ & p value & $\mathrm{n}$ \\
\cline { 1 - 3 } $\begin{array}{l}\text { Kelompok } \\
\text { Eksperimen }\end{array}$ & 15.50 & 155.00 & & \\
$\begin{array}{l}\text { Kelompok } \\
\text { Kontrol }\end{array}$ & 5.50 & 55.00 & & \\
\hline
\end{tabular}

Berdasarkan tabel di atas dapat diketahui bahwa perbedaan skor selisih rata-rata $P O N V$ pada kelompok eksperimen dengan kelompok kontrol adalah 10.00. Hasil analisis uji ManWhitney didapatkan nilai $p$ value $0.000<\alpha$ (0.05), maka dapat disimpulkan bahwa terdapat perbedaan skor selisih rata-rata $P O N V$ pada kelompok eksperimen dengan kelompok kontrol. Hal ini berarti bahwa kombinasi antiemetik dengan terapi aromatik peppermint inhalasi lebih efektif dalam menurunkan skor PONV dibandingkan kombinasi antiemetik dengan plasebo.

\section{PEMBAHASAN}

Hasil penelitian menggambarkan bahwa telah terjadi penurunan skor ratarata $P O N V$ pada pasien post operasi yang diberikan premedikasi antiemetik dengan pemberian aromaterapi peppermint inhalasi pada kelompok eksperimen dari rata-rata skor 14.40 menjadi 3.30. Terapi aromatik peppermint inhalasi berkontribusi terhadap menurunkan rata-rata skor $P O N V$ sebesar 11,1 pada pasien post operasi dengan anastesi umum.

Sedangkan hasil pada kelompok kontrol juga mengambarkan telah terjadi penurunan rata-rata skor $P O N V$ pada pasien post operasi yang diberikan premedikasi antiemetik dengan pemberian plasebo dari skor rata-rata 9.70 menjadi 7.50. Penurunan rata-rata skor $P O N V$ pada kelompok kontrol hanya sebesar 2,20. Hal ini tentu berbeda jauh dengan penurunan rata-rata skor $P O N V$ pada kelompok eksperimen yang angka penurunannya mencapai 11,1 .

Berdasarkan perbedaan rata-rata penurunan skor $P O N V$ pada kelompok eksperimen dan kontrol yang nilainya mencapai angka 8,9, menunjukan bahwa pemberian premedikasi entiemetik dengan pemebrian terapi aromatik peppermint inhalasi pada pasien post operasi memberikan efek penurunan mual muntah yang lebih baik daripada hanya diberikan terapi antemetik saja.

Penurunan rata-rata skor $P O N V$ yang cukup besar pada kelompok eksperimen dibandingkan kelompok kontrol dipengaruhi oleh efek premedikasi obat antiemetik dan juga karena efek dari terapi aromatik peppermint inhalasi. Pada penelitian ini, jenis obat antiemetik yang yang digunakan untuk mencegah atau mengobati mual muntah post operasi $(P O N V)$ adalah ondansentron, dengan dosis yang diberikan sebesar yaitu $2,5 \mathrm{mg}$, sedangkan terapi aromatik dengan menggunakan aroma peppermint yang diberikan secara inhalasi.

Ondansentron merupakan obat golongan antagonis reseptor $5-\mathrm{HT}_{3}$ yang berkerja menghambat reseptor serotinin pada sistem saraf serebral dan saluran pencernaan, sehingga obat ini dapat mengobati mual dan muntah post operasi.

Menurut Anderson et al. (2002) dalam Utomo, Sudirman \& Syafi'i, (2009) ondansentron adalah obat selektif terhadap reseptor antagonis 5-Hidroksi-Triptamin $\left(5-\mathrm{HT}_{3}\right)$ di otak dan juga pada aferen vegal saluran cerna, dimana selektif dan kompetitif untuk mencegal mual dan muntah setelah operasi dan radioterapi.

Penurunan skor PONV pada kelompok eksperimen selain karena faktor obat entiemetik juga disebabkan karena tambahan pemebrian terapi aromatik pepppermint inhalasi. 
Berdasarkan hasil penilaian ulang mual muntah didapatkan rata-rata responden mengatakan rasa mual ataupun ingin muntah berkurang bahkan menghilang setelah diberikan aromaterapi peppermint inhalasi. Menurut peneliti, respon ini terjadi karena molekul-molekul yang terdapat pada aromaterapi peppermint ini dihirup dan merangsang syaraf penciuman kemudian menuju syaraf pusat yang pada akhirnya menimbulkan sensasi rileks sehingga rasa mual dan muntah berkurang.

Hasil analisis penelitian Supatmi \& Agustiningsih (2015) mengatakan aromaterapi bekerja dengan mengalihkan stimulus mual dan muntah ke stimulus rileks dan segar, hal ini membuat reflek mual menjadi hilang atau berkurang.

Selain itu, hasil analisis penelitian Susanti (2016) mengatakan penggunaan inhalasi aromaterapi peppermint selama 5 menit dapat berpengaruh terhadap penurunan skala mual pada pasien kemoterapi. Hal ini karena inhalasi aromaterapi peppermint berpengaruh secara langsung terhadap saraf-saraf di otak sehingga efeknya dapat dirasakan secara langsung oleh pasien setelah menghirupnya. Secara farmakologi, wewangian dari essential oil (EO) dapat mengirimkan efek secara langsung pada sistem saraf pusat dan sistem endokrin tanpa sadar. Melalui inhalasi, molekulmolekul volatile minyak esensial yang melewati reseptor olfaktori di hidung mengenali karakteristik molekuler tersebut dan mengirimkan sinyal ke otak melalui saraf olfaktori dan beberapa unsur pokok dari molekul tersebut masuk ke dalam aliran darah melalui paru-paru dan berpengaruh secara langsung terhadap saraf-saraf di otak setelah melewati barier darah di otak.

Berdasarkan analisis menggunakan GC-MC (Gas Chromatography-Mass Spectrometry), essential oil (EO) atau minyak atsiri peppermint (M. $x$ piperita) mengandung 5 komponen dari 14 komponen yang dievaluasi dapat berfungsi sebagai anti mual muntah. Komponen tersebut diantaranya yaitu Limonene
(5,96\%), cis-Dihydrocarvone (19,19\%), Pulegone (13,30\%), Carvone (42,53\%), $\beta$ Caryphyllene $\quad(6,78 \%) \quad$ sehingga aromaterapi peppermint dapat menurunkan skala mual akibat kemoterapi (Susanti, 2016).

Aromaterapi peppermint mempunyai fungsi salah satunya dalam menurunkan terjadinya mual dan muntah (Snyder dan Lindquist, 2010 dalam Supatmi \& Agustiningsih, 2015). Peppermint juga telah lama dikenal memberi efek karminatif dan antispasmodik, secara khusus bekerja diotot halus saluran gastrointestinal dan saluran empedu (Santi, 2013).

Menurut Collins (2008) dalam Supatmi \& Agustiningsih (2015) aromaterapi inhalasi mengirimkan pesan ke bagian olfaktorius, yang kemudian proses ini dilanjutkan dengan pengelolaan impuls pada sistem limbik otak. Aromaterapi menimbulkan persepsi yang segar, relaksasi dan nyaman bagi pasieen. Kondisi ini dapat menekan stimulasi stress yang menyebabkan tubuh merasa nyaman serta dapat menekan reflek mual dan muntah (Cook, 2008 dalam Supatmi \& Agustiningsih, 2015).

Hasil analisis statistik lebih lanjut dengan uji Wilcoxon pada kelompok eksperimen didapatkan $p$ value $0.005<\alpha$ (0.05), maka disimpulkan bahwa terdapat perbedaan skor rata-rata $P O N V$ sebelum dan setelah diberikan kombinasi antiemetik dan aromaterapi peppermint inhalasi pada kelompok ekperimen.

Hasil analisis data di atas, sejalan dengan hasil penelitian Susanti (2016) yang menyatakan terdapat perbedaan ratarata skala mual sebelum dan setelah pemberian aromaterapi peppermint pada pasien yang menjalani kemoterapi sebesar. Hal ini berarti terdapat pengaruh pemberian aromaterapi peppermint terhadap penurunan skala mual pada pasien kemoterapi.

Hasil penelitian ini juga sejalan dengan penelitian Santi (2013) yang menyimpukan bahwa terdapat pengaruh aromaterapi blended peppermint dan 
ginger oil terhadap rasa mual pada ibu hamil trimester satu.

Hasil analisis statistik lebih lanjut dengan uji Wilcoxon pada kelompok kontrol didapatkan $p$ value $0.006<\alpha$ (0.05). Hasil tersebut menyimpulkan bahwa terdapat perbedaan rata-rata skor $P O N V$ pada sebelum dan setelah pemberian plasebo pada kelompok kontrol.

Peneliti berpendapat bahwa penurunan skor rata-rata $P O N V$ pada kelompok kontrol lebih banyak dipengaruhi oleh pemberian premedikasi obat antiemetik. Sebagaimana yang telah dijelaskan sebelumnya, obat antiemetik dengan golongan antagonis reseptor $5-\mathrm{HT}_{3}$ yaitu ondasentron ini menghambat reseptor serotinin pada sistem saraf serebral dan saluran pencernaan, sehingga dapat mengobati mual dan muntah post operasi.

Durasi pasien dalam mengalami mual muntah post operasi pada kelompok kontrol ini ada yang hingga berjam-jam kemudian menurun dengan bertahap, namun ada juga yang belum tampak adanya penurunan hingga 12 jam post operasi.

Menurut Qudsi \& Jatmiko (2015), mual muntah post operasi (PONV) dapat berlangsung dalam beberapa menit, jam dan hari yang terdiri dari 2 tahap yaitu tahap akut dan tahap lanjut. Tahap akut yaitu terjadi dalam 2-6 jam post operasi dan tahap lanjut terjadi hingga 24-48 post operasi. Sedangkan, menurut Burden (2000) dalam Supatmi \& Agustiningsih (2015) kondisi akut mual muntah ini dapat terjadi pada 24 jam pertama post operasi.

Rasa mual muntah post operasi ini dapat menurun dengan sendirinya seiring waktu, hal ini bisa disebabkan karena efek dari obat anestesi yang bertahap menghilang. Respon terhadap mual muntah yang ditemui tiap pasiennya tentunya berbeda. Hal ini dapat dipengaruhi oleh berbagai faktor. Sebagaimana faktor yang mempengaruhi $P O N V$ antara lain ada faktor pasien, faktor prosedur dan faktor anestesi (Qudsi \& Jatmiko, 2015), dari faktor tersebut dapat mempengaruhi proses penurunan mual muntah post operasi $(P O N V)$. Jika faktor resiko rendah, kemungkinan penurunan skor rata-rata $P O N V$ lebih terlihat.

Pada kelompok kontrol ini, peneliti memberikan intervensi pemberian plasebo menggunakan air hangat yang diinhalasi. Rata-rata responden kelompok kontrol yang diberikan plasebo ini mengatakan tidak merasakan perubahan apapun setelah diberikan terapi. Pemberian plasebo pada kelompok kontrol ini memang merupakan penanganan palsu yang tidak memberikan efek terhadap pengobatan.

Berdasarkan hasil penelitian pada tabel 4.7 dapat diketahui bahwa skor selisih rata-rata $P O N V$ pada kelompok eksperimen adalah 15.50 dan skor selisih rata-rata $P O N V$ pada kelompok kontrol adalah 5.50, maka perbedaan skor selisih rata-rata $P O N V$ pada kelompok eksperimen dengan kelompok kontrol adalah 10.00. Hasil ini menunjukkan bahwa skor selisih rata-rata $P O N V$ pada kelompok eksperimen lebih besar dibandingkan dengan kelompok kontrol.

Hasil penelitian juga mengambarkan bahwa hasil analisis uji Man-Whitney didapatkan nilai $p$ value $0.000<\alpha(0.05)$, maka disimpulkan bahwa pemberian terapi aromatik peppermint inhalasi lebih efektif dibandingkan terapi plasebo terdapat dalam menurunkan rata-rata skor $P O N V$ pasien post operasi anastesi umum dengan premedikasi antiemetik.

Penelitian ini sejalan dengan penelitian Supatmi \& Agustiningsih (2015) yang berjudul "Efek Aromatherapy Peppermint Inhalasi terhadap Mual dan Muntah pada Pasien dengan Pemberian Kemoterapi" yang menyimpulkan bahwa adan perbedaan kejadian mual dan muntah pada kelompok kontrol dan kelompok intervensi. Tingkat kejadian mual dan muntah pada kelompok intervensi lebih rendah dibanding kelompok kontrol $(\mathrm{p}=0,027)$. Penelitian ini menyimpulkan secara umum aromaterapi jenis peppermint yang diberikan secara inhalasi, efektif menurunkan mual dan muntah pada pasien.

Aromaterapi jenis peppermint ini adalah salah satu dari terapi non farmakologi (komplementer) yang dapat digunakan untuk mengatasi mual muntah 
pada pasien post operasi. Dengan metode yang diberikan adalah secara inhalasi sebab aromaterapi yang digunakan dengan metode inhalasi memiliki rute yang jauh lebih cepat penanggulannya dibandingkan metode lain.

Pada penelitian ini, telah terlihat terapi yang jauh lebih memberikan pengaruh dalam menurunkan skor rata-rata $P O N V$ antara kelompok eksperimen yang diberikan terapi premedikasi obat antiemetik yang disertai pemberian aromaterapi peppermint inhalasi dengan kelompok kontrol yang diberikan terapi premedikasi obat antiemetik yang disertai pemberian plasebo, dengan hasil yang didapatkan penurunan skor rata-rata $P O N V$ pada kelompok eksperimen jauh lebih besar dibandingkan dengan kelompok kontrol.

Oleh karena itu, pemberian aromaterapi ini dapat dijadikan intervensi dalam melakukan asuhan keperawatan dalam memenuhi kebutuhan dasar manusia yaitu kebutuhan nutrisi maupun cairan pasien, karena jika pasien mengalami mual muntah maka pemenuhan nutrisi maupun cairan pasien dapat berkurang bahkan yang lebih dikhawatirkan lagi efek lebih lanjutnya pasien akan mengalami antara lain dehidrasi, ketidakseimbangan elektrolit, hipertensi vena, perdarahan, ruptur esofageal, dan dalam keadaan lanjut dapat membuat pasien mengalami dehidrahi berat (Conway, 2009 dalam Supatmi \& Agustiningsih, 2015).

Aromaterapi sebenarnya telah digunakan sejak lama. Pada awal abad ke19, aromaterapi mulai digunakan dalam praktek pengobatan barat. Tentara Prancis yang kembali dari Perang Dunia I diobati dengan minyak aromaterapi untuk menyembuhkan luka, merawat kecemasan dan meringankan depresi.

Asuhan keperawatan pada pasien post operasi di banyak rumah sakit di Indonesia, belum menjadikan pemberian aromaterapi peppermint ini sebagai intervensi dalam memberikan asuhan keperawatan untuk menangani mual muntah post operasi. Namun beberapa rumah sakit telah mencoba menerapkan aroma terapi diantaranya adalah RSPAD Gatot Soebroto Jakarta Pusat. Jenis aromaterapi yang digunakan di rumsah sakit ini adalah serai untuk mengatasi kecemasan.

Jika ditinjau dari aspek legal, perawat diperkenankan menerapkan terapi komplementer, sebagaimana telah diatur dalam UU No. 38 Tahun 2014 tentang Keperawatan pada pasal 30 ayat (2) huruf $m$ yang menyatakan: dalam menjalankan tugas sebagai pemberi asuhan keperawatan di bidang upaya kesehatan masyarakat, perawat berwenang melakukan penatalaksanaan keperawatan komplementer dan alternatif. Maksud dari isi pasal 30 ayat (2) huruf m pada kalimat "melakukan penatalaksanaan keperawatan komplementer dan alternatif" adalah bagian dari penyelenggaraan praktik keperawatan dengan memasukan terapi komplementer dan alternatif dalam pelaksanaan asuhan keperawatan.

Sehingga, dalam mengatasi keluhan mual muntah post operasi tidak hanya bisa dengan pemberian intervensi menggunakan terapi farmakologi saja namun bisa didampingi oleh terapi komplementer, salah satunya adalah aromaterapi peppermint.

\section{KESIMPULAN}

Penelitian ini menyimpulkan bahwa pemberian terapi aromatik peppermint secara inhalasi pada pasien post operasi dengan anastesi umum dapat menurunkan intensitas mual muntah yang ditunjukan dengan penurunan rata-rata skor $P O N V$. Pemberian terapi aromatik pappermint memberikan efek penurunan intensitas mual dan muntah yang lebih cepat pada pasien post operasi dengan anastesi umum dibandingkan hanya mengandalkan efek farmakologis dari premedikasi antiemetik.

Hal ini karena inhalasi essential oil (EO) aromaterapi peppermint secara farmakologi mempengaruhi sistem saraf pusat dan sistem endokrin. Melalui proses inhalasi, molekul-molekul volatile minyak esensial yang melewati reseptor olfaktori 
akan mengenali karakteristik molekuler tersebut dan mengirimkan sinyal ke otak melalui saraf olfaktori dan beberapa unsur pokok dari molekul tersebut masuk ke dalam aliran darah melalui paru dan berpengaruh secara langsung terhadap saraf-saraf di otak setelah melewati barier darah di otak.

Kandungan zat-zat seperti limonene, cis-dihydrocarvone, pulegone, carvone dan $\beta$-caryphyllene pada minyak atsiri peppermint dapat berfungsi sebagai anti mual muntah. Terapi aromatik peppermint dapat menimbulkan persepsi segar, rileks dan nyaman pada pasien. Kondisi ini dapat menekan stimulasi stress, sehingga dapat menekan reflek mual dan muntah sehingga tubuh menjadi lebih nyaman.

Dengan demikian, maka terapi aromatik peppermint dapat dijadikan salah satu alternatif intervensi keperawatan pada asuhan keperawatan pasien yang mengalami mual dan muntah, khususnya pasien post operasi dengan anastesi umum.

\section{DAFTAR PUSTAKA}

Hartoyo, P.J. (2015). Hubungan antara karakteristik demografi dengan pengetahuan mobilisasi dini pada pasien post operasi laparatomi di RS. PKU Muhammadiyah Bantul. http://thesis.umy.ac.id/index.php?op $\mathrm{o}=$ popUpBibliografi\&id $=58440 \& \mathrm{cs}=$ 1. Diperoleh tanggal 7 Januari 2017.

Indrawati, Apriliyani. (2010). Efektivitas Rangsangan Kombinasi Titik Akupunktur Pc-6 (Neiguan) \& St-25 (Tianshu) Dibandingkan Pemberian Ondansetron Untuk Mencegah Mual dan Muntah Pasca Bedah Ortopedi dengan Anestesi Umum. http:// eprints.ums.ac.id/10216/4/J50006003 3.pdf. Diperoleh tanggal 17 Januari 2017.

Juliana, Y. H., Irawan, D., Hamidy, M.Y. (2013). Gambaran Kejadian Post Operative Nausea And Vomiting (PONV) pada Pasien yang Menjalani Anestesi Umum dengan Menggunakan Laryngeal Mask
Airway (Lma) di Rsud Arifin Achmad Provinsi Riau. http:// repository.unri.ac.id/jspui/handle/123 456789/2531. Diperoleh tanggal 14 Januari 2017.

Qudsi, A. S., \& Dwi Jatmiko, H. (2015). Prevalensi Kejadian PONV pada Pemberian Morfin sebagai Analgetik Pasca Operasi Penderita Tumor Payudara dengan Anestesi Umum di RSUP Dr. Kariadi Semarang. http://id.portalgaruda.org/?ref=brows e\&mod+viewarticle\&article $=46294$. Diperoleh tanggal 20 Januari 2017.

Santi, Dwi Sukma. (2013). Pengaruh Aromaterapi Blended Peppermint dan Ginger Oil terhadap Rasa Mual pada Ibu Hamil Trimester Satu Di Puskesmas Rengel Kabupaten Tuban. Jurnal Sain Med, Vol. 5. No. 2, 52-55.

Sholihah, A., Sikumbang, K.M., \& Husairi, A. (2015). Gambaran Angka Kejadian Post Operative Nausea And Vomiting (PONV) di Rsud Ulin Banjarmasin Mei-Juli 2014. Jurnal Berkala Kedokteran, 11 (1), 119129.

Silaban, J. H. (2015). Perbandingan Penurunan Resiko Kejadian Mual Muntah Pasca Operasi dengan Pemberian Midazolam 0,035 mgkgiv dan Ondansetron 4 mgiv pada Pasien dengan Skor Apfel 3-4 yang Dilakukan Anestesi. http:// repository.usu.ac.id/handle/1234567 89/52932. Diperoleh tanggal 11 Januari 2017.

Solehati, T., \& Kosasih, C.E. (2015). Konsep \& Aplikasi Relaksasi dalam Keperawatan Maternitas. Bandung : PT Refika Aditama.

Supatmi \& Agustiningsih. (2015). Efek Aromatherapy Pepermint Inhalasi terhadap Mual dan Muntal pada Pasien dengan Pemberian Kemoterapi. http://jurnal.akeskaryahusada. ac.id/index.php/jkkh/article/view/19. Diperoleh tanggal 7 Januari 2017.

Susanti, Dwi Novi. (2016). Pengaruh Aromaterapi Peppermint terhadap Penurunan Skala Mual pada Pasien 
Kemoterapi di Rsud Panembahan Senopati Bantul. http://repository. umy.ac.id/bitstream/handle/1234567 89/2940/NASKAH\%20PUBLIKASI. pdf? sequence $=12$ \&isAllowed $=y$. Diperoleh tanggal 11 Januari 2017.

Utomo, A. K., Sudirman, S., \& Syafi'i, I., (2009). Perbandingan Efektivitas antara Akupunktur PC-6 dan Ondansetron dalam Mencegah Insidensi Mual dan Muntah Pasca
Bedah Ortopedi. Jurnal Kedokteran Indonesia, 1(1), 25-31.

Wijaya, A.A., Fithrah, B.A., Marsaban, A.H.M., \& Hidayat, Jefferson. (2014). Efektivitas Pemberian Cairan Praoperatif Ringer Laktat 2 $\mathrm{mL} / \mathrm{kgBB} / \mathrm{jam}$ Puasa untuk Mencegah Mual Muntah Pascaoperasi. Jurnal Anestesi Perioperatif, 2 (3), 200-207. 